\title{
Evaluation of Cyanide Content, Volatile Compounds Profile, and Biological Properties of Fresh and Boiled Sliced Thai Bamboo Shoot (Dendrocalamus asper Back.)
}

\author{
Paponpat Pattarathitiwat ${ }^{1}$, Chakorn Chinvongamorn ${ }^{2}$, and Sompong Sansenya ${ }^{2}$ \\ ${ }^{1}$ Department of Food and Nutrition, Faculty of Home Economics Technology and ${ }^{2}$ Department of Chemistry, \\ Faculty of Science and Technology, Rajamangala University of Technology Thanyaburi, Pathum Thani 12110, Thailand
}

\begin{abstract}
This study evaluated the cyanide content, bio-active compounds profile, volatile compounds profile, and biological activity of fresh and boiled sliced bamboo. Cyanide was only detected in fresh bamboo shoots, at a content of $140.40 \pm 5.34 \mathrm{mg} / \mathrm{kg}$. Furthermore, the fresh bamboo shoots extracts had free radical scavenging properties, as demonstrated by $\mathrm{ABTS}^{\circ}{ }^{+}$and $\mathrm{DPPH}^{\circ}$ assays, and contained phytochemical compounds, such as flavonoid, terpenoid, and reducing sugar. Indeed, the total phenolic and flavonoid contents were $12.12 \pm 0.12 \mathrm{mg}$ gallic acid equivalent $/ \mathrm{dw}$ and $1.60 \pm$ $0.11 \mathrm{mg}$ quercetin equivalent/dw, respectively. In addition, these extracts demonstrated inhibitory activity against $\alpha$-glucosidase (61.30 $\pm 0.45 \%), \alpha$-amylase $(37.00 \pm 1.82 \%)$, and tyrosinase $(26.57 \pm 0.57 \%)$. Some volatile compounds, such as 2-methoxyphenol and 2-pentylfuran, show $\alpha$-glucosidase inhibitory activity, and these compounds exerted $\alpha$-amylase inhibitory activity in the fresh sliced bamboo shoots. The major volatile compound 4-methylphenol (68.15\%), which exerts tyrosinase inhibitory activity, was also detected in fresh sliced bamboo shoots. The boiled sliced bamboo shoots extracts also contained bio-active compounds and exhibited biological activity similar to those in the fresh sliced bamboo shoots extracts. However, the boiling process and sliced technique reduced the bio-active compounds and biological properties as well as some of volatile compounds.
\end{abstract}

Keywords: $\alpha$-glucosidase and $\alpha$-amylase inhibitory activity, cyanide content, free radical scavenging assays, Thai bamboo shoots, tyrosinase inhibitory activity

\section{INTRODUCTION}

Bamboo shoots had been used as an ingredient for food and in traditional medicine (Wang et al., 2020). Bamboo shoots contain a variety of nutrients beneficial for human health, including vitamins, proteins, minerals, fats, fiber, and bio-active compounds, such as phenolic and flavonoid compounds (Zhang et al., 2011; Nongdam and Tikendra, 2014). The nutritional content of bamboo shoots varies depending on the species and environmental factors (Chongtham et al., 2011; Satya et al., 2012). The bio-active compounds contained in bamboo shoots exhibit biological activities, including antioxidant (Bajwa et al., 2018), anti-bacterial (Tanaka et al., 2011), and anti-allergy (Tanaka et al., 2014) activities. Bamboo shoot extracts have also been used for treatment of chronic diseases, such as diabetes (by reducing hyperglycemia) and cancer (Panee, 2009). Furthermore, they had been used as in cosmetic products, such as anti-aging products (Nirmala and Bisht, 2015). Although bamboo shoots are rich in biochemical compounds and have nutritional benefit for human health, the fresh bamboo shoots have some toxin compounds known as cyanide. Cyanide exists as cyanogenic glycoside in bamboo shoots, with its the content varying depending on the species and the portion of bamboo shoots (Satya et al., 2012). Cyanide at a content of $0.5 \sim 3.5 \mathrm{mg} / \mathrm{kg}$ body weight demonstrates acute effects on human health (Pandey and Ojha, 2014). However, the cyanide content can be eliminated during cooking processes such as boiling, streaming, heating, and frying (Pandey and Ojha, 2014).

Bamboo belongs to the family Poaceae, which consists of over 1,642 species distributed throughout the world, especially in Asia. In Thailand, Dendrocalamus asper are important edible plants (Maoyi et al., 1987). The macronutrient content ( $\mathrm{g} / 100 \mathrm{~g}$ fresh weight) of Dendrocalamus 
asper were identified by Chongtham et al. (2011): amino acid, 3.12 \pm 0.07 ; protein, 3.59 \pm 0.06 ; carbohydrate, 4.90 \pm 0.11 ; starch, $0.39 \pm 0.08$; fat, $0.40 \pm 0.06$; dietary fiber, 3.54 \pm 0.07 ; vitamin C, $3.20 \pm 0.06$; vitamin E, $0.91 \pm 0.31$. Dendrocalamus asper bamboo shoots have many nutritional benefits for human health. However, reports on of bio-active profile, volatile compound profile, and biological activity of this species are limited. In this study, we investigated the bio-active compound profile, volatiles compound profile, and biological activity (e.g., antioxidant activity and enzyme inhibition activity) related to diabetes mellitus and melanin synthesis in fresh and boiled sliced bamboo shoots.

\section{MATERIAL AND METHODS}

\section{Chemical reagents}

All chemical reagents used for this experiment were purchased from Sigma-Aldrich Co. (St. Louis, MO, USA). Enzymes used for enzymatic inhibition assays were $\alpha$-glucosidase (from Saccharomyces cerevisiae), $\alpha$-amylase (from Aspergillus oryzae), and tyrosinase (from mushrooms). The substrate used were $p$-nitrophenyl- $\alpha$-glucopyranoside (4-pNPG) for $\alpha$-glucosidase, amylose for $\alpha$-amylase, and 3,4-dihydroxy-L-phenylalanine (L-DOPA) for tyrosinase. Reagents for radical scavenging assay used include 2,2diphenyl-1-picrylhydrazyl (DPPH $\left.{ }^{\circ}\right)$ and 2,2'-azino-bis (3ethylbenzthiazoline-6-sulphonic acid) $\left(\right.$ ABTS $\left.^{\circ+}\right)$, and the cyanide test kit Quantofix ${ }^{\circledR}$ (Sigma-Aldrich Co.).

\section{Plant material}

Pai Tong bamboo shoots (Dendrocalamus asper Back.) were harvested from Thung Pho, Nadi District, Prachin Buri Province, Thailand. Bamboo shoots (1,000 g) were shelled, washed with deionized water, and sliced [approximate slice size of $15 \mathrm{~mm}$ (width) $\times 0.5 \mathrm{~mm}$ (depth) $\times 30$ $\mathrm{mm}$ (length)]. Sliced samples (500 g) were then heated in boiling water $(1,000 \mathrm{~mL})$ for $30 \mathrm{~min}$. The fresh and boiled samples were kept at $-20^{\circ} \mathrm{C}$ until extraction.

\section{Sample extraction}

Fresh and boiled samples (500 g) were ground thoroughly with liquid nitrogen to produce a powder. Powdered samples (300 g) were extracted with $300 \mathrm{~mL}$ methanol for 7 days. The extraction was centrifuged at $6,000 \mathrm{rpm}$ for $20 \mathrm{~min}$ to remove bamboo residue, and methanol in the supernatant was removed by a hot air oven at $50^{\circ} \mathrm{C}$. The crude extract was kept at $-20^{\circ} \mathrm{C}$ until phytochemical screening, bio-active compound profile determination, radical scavenging efficiency assays, and enzyme inhibition evaluation.

\section{Cyanide quantification}

Fresh and boiled samples (50 g) were ground thoroughly to produce small pieces. The samples were extracted with extraction buffer $\left[1.0 \mathrm{~mL}\right.$ of $\mathrm{CdCl}_{2}(50 \mathrm{~g} / \mathrm{L})$ and $10 \mathrm{~mL}$ of potassium phosphate buffer $(\mathrm{pH} \mathrm{6)}$ ] and incubated for $15 \mathrm{~min}$ at room temperature. The solution was then centrifuged at 6,000 rpm for $15 \mathrm{~min}$, and the supernatant was filtrated through a $0.45 \mu \mathrm{m}$ syringe filter. The cyanide content was determined using Quantofix ${ }^{\circledR}$ cyanide test kit.

\section{Phytochemical screening}

The presence of phytochemical components, including flavonoids, terpenoid, and reducing sugar, were determined following the method of Sansenya and Nanok (2020), with modifications. First, the crude methanol extract was dissolved in deionized water to produce $1 \mathrm{mg} / \mathrm{mL}$ solutions. To determine the flavonoid content, $4 \mathrm{~mL}$ of solution was mixed with $1 \mathrm{~mL}$ of ammonia. A positive result was obtained when the solution changed to a yellow color, indicating that the sample contains flavonoid. To detect terpenoid, $2 \mathrm{~mL}$ of solution was mixed with $2 \mathrm{~mL}$ of chloroform and mixed by shaking. The solution was then mixed with $3 \mathrm{~mL}$ of concentrated $\mathrm{H}_{2} \mathrm{SO}_{4}$, following which a reddish-brown color indicated a positive result. To detect reducing sugar, $5 \mathrm{~mL}$ of sample was mixed with $2 \mathrm{~mL}$ of benedict solution under base condition. The mixture was then boiled for 10 min or until a brick-red precipitate is formed, indicating the presence of reducing sugar.

\section{Volatile compound profile determination}

Bamboo shoots (fresh and boiled samples) were cut into small pieces with a knife and approximately $4 \mathrm{~g}$ was added into $20 \mathrm{~mL}$ headspace vials and capped. Samples were pre-heated at $50^{\circ} \mathrm{C}$ for $10 \mathrm{~min}$, and volatile compounds were extracted using a solid phase microextraction fiber (50/30 $\mu \mathrm{m}$ divinylbenzene/carboxen/polydimethylsiloxane, Supelco, Bellefonte, PA, USA) for $20 \mathrm{~min}$. The fiber was desorbed using a gas chromatography injector port at $250^{\circ} \mathrm{C}$ for $5 \mathrm{~min}$. Separation of the desorbed volatiles were achieved by gas chromatography-mass spectrometry (Agilent 7890A GC-7000 Mass Triple Quad, Agilent Technologies, Inc., Santa Clara, CA, USA) equipped with a capillary column (DB-WAX, $60 \mathrm{~m} \times 0.25 \mathrm{~mm} \times 0.25$ $\mu \mathrm{m}, \mathrm{J} \& \mathrm{~W}$ Scientific, Folsom, CA, USA) and a quadrupole mass detector. The injector was operated at split mode with a split ratio of 5:1. Helium gas was used as the carrier gas with a constant flow rate of $0.8 \mathrm{~mL} / \mathrm{min}$. The gas chromatography oven temperature started at $32^{\circ} \mathrm{C}$ for 10 min, increased to $40^{\circ} \mathrm{C}$ at $3^{\circ} \mathrm{C} / \mathrm{min}$ and held for $15 \mathrm{~min}$, increased to $160^{\circ} \mathrm{C}$ at $3^{\circ} \mathrm{C} / \mathrm{min}$, then increased to $230^{\circ} \mathrm{C}$ at $4^{\circ} \mathrm{C} / \mathrm{min}$ and then held for $5 \mathrm{~min}$. The mass spectrometer was used in the electron ionization mode with the ion source temperature set at $230^{\circ} \mathrm{C}$, and the ionization 
energy set at $70 \mathrm{eV}$. The scan mode was used and the scan range was 25 to $400 \mathrm{~m} / \mathrm{z}$. The MassHunter Qualitative Analysis B.04.00 software (Agilent Technologies, Inc.) was used for data analysis. Identification of volatile compounds was performed by comparing mass spectra with National Institute of Standards and Technology mass spectral libraries (2011 version, National Institute of Standards and Technology, Gaithersburg, MD, USA). Volatile compound contents were calculated from peak areas.

\section{Phenolic content and flavonoid content determination}

Total phenolic and flavonoid contents were determined by the methods of Pourmorad et al. (2006), with modifications. The total phenolic content was determined by mixing the sample solution $(1 \mathrm{mg} / \mathrm{mL})$ with Folin-Ciocalteu reagent and $10 \%(\mathrm{w} / \mathrm{v})$ sodium carbonate, and the reaction was incubated in the dark. The final product was measured at $715 \mathrm{~nm}$ using an ultraviolet-visible (UV/Vis) spectrophotometer. The total phenolic contents of fresh and boiled bamboo shoots were calculated against calibration curves of gallic acid [milligrams of gallic acid equivalent (mg GAE) per gram of dry weight (dw)]. The total flavonoid content was determined by mixing the sample solution $(1 \mathrm{mg} / \mathrm{mL})$ with $5 \%$ of $\mathrm{NaNO}_{2}, 10 \%$ of $\mathrm{AlCl}_{3}$, and $1 \mathrm{M}$ of $\mathrm{NaOH}$. The reaction mixture was incubated at the room temperature. The final product was measured at $415 \mathrm{~nm}$ by using a UV/Vis spectrophotometer. The total flavonoid content was calculated against a calibration curve of quercetin [milligrams of quercetin equivalent (mg QE) per gram of dw].

\section{Radical scavenging efficiency assays}

Radical scavenging activities of fresh and boiled bamboo shoots extracts were determined using $\mathrm{DPPH}^{\circ}$ and ABTS $^{*+}$ assays. For DPPH ${ }^{*}$ assays, sample solution (10 $\mu \mathrm{L}$ ) was mixed with $90 \mu \mathrm{L}$ of $0.1 \mathrm{mM} \mathrm{DPPH}$ and the mixture was incubated at room temperature in the dark for $15 \mathrm{~min}$. The absorbance of the final product was determined using a UV/Vis spectrophotometer at $517 \mathrm{~nm}$. For $\mathrm{ABTS}^{++}$assays, sample solution $(10 \mu \mathrm{L})$ was mixed with $90 \mu \mathrm{L}$ of $\mathrm{ABTS}^{\circ}$, and the mixture was incubated at room temperature in the dark for $6 \mathrm{~min}$. The absorbance of the final product was determined using a UV/Vis spectrophotometer at $734 \mathrm{~nm}$. The percentage of inhibition was calculated as following:

$$
\text { Inhibition }(\%)=\frac{A_{0}-A_{s}}{A_{0}} \times 100
$$

where $A_{0}$ is absorbance without sample and $A_{s}$ is absorbance with sample.

\section{Enzyme inhibition assays}

The enzyme inhibitory assays of crude methanol extracts of fresh and boiled bamboo shoots were investigated by following the method of Sansenya et al. (2021), with modifications. For $\alpha$-glucosidase activity assays, 4-pNPG was used as the substrate. Sample solution $(10 \mu \mathrm{L} ; 1.0$ $\mathrm{mg} / \mathrm{mL}$ ) was mixed with $5.0 \mu \mathrm{L}$ of $\alpha$-glucosidase (0.05 $\mathrm{mg} / \mathrm{mL}$ ), $5.0 \mu \mathrm{L}$ of $4-p N P G(5 \mathrm{mM})$, and $80 \mu \mathrm{L}$ of $50 \mathrm{mM}$ phosphate buffer $\mathrm{pH}$ 6.8. The mixture was incubated at $30^{\circ} \mathrm{C}$ for $30 \mathrm{~min}$, before the reaction was stopped by addition of $100 \mu \mathrm{L}$ of $0.5 \mathrm{M} \mathrm{Na}_{2} \mathrm{CO}_{3}$. The final product was measured at $405 \mathrm{~nm}$ by using a spectrophotometer. For $\alpha$-amylase activity assays, amylose was used as the substrate. Sample solution $(10 \mu \mathrm{L} ; 1.0 \mathrm{mg} / \mathrm{mL})$ was mixed with $10 \mu \mathrm{L}$ of $\alpha$-amylase $(0.05 \mathrm{mg} / \mathrm{mL}), 10 \mu \mathrm{L}$ of amylose $(0.05 \mathrm{mg} / \mathrm{mL})$, and $70 \mu \mathrm{L}$ of $20 \mathrm{mM}$ phosphate buffer $\mathrm{pH}$ 6.8. The mixture was incubated at $30^{\circ} \mathrm{C}$ for $30 \mathrm{~min}$, before the reaction was stopped by boiling in boiling water for $5 \mathrm{~min}$. Release of reducing sugars (glucose) was determined by peroxidase-glucose oxidase assays at $475 \mathrm{~nm}$ using a UV/Vis spectrophotometer. For tyrosinase activity assays, L-DOPA was used as the substrate. Sample solution $(10 \mu \mathrm{L} ; 1.0 \mathrm{mg} / \mathrm{mL})$ was mixed with $5 \mu \mathrm{L}$ of tyrosinase $(0.1 \mathrm{mg} / \mathrm{mL})$ and $80 \mu \mathrm{L}$ of $20 \mathrm{mM}$ phosphate buffer $\mathrm{pH} 6.8$. The mixture was incubated at $37^{\circ} \mathrm{C}$ for 20 min, following which $5 \mu \mathrm{L}$ of L-DOPA $(5 \mathrm{mM})$ was added, and then the mixture was incubated at $37^{\circ} \mathrm{C}$ for a further $20 \mathrm{~min}$. The final product was measured at $492 \mathrm{~nm}$ by a spectrophotometer. The percentages of inhibition ( $\alpha$-glucosidase, $\alpha$-amylase, and tyrosinase) were calculated as follows:

$$
\text { Inhibition }(\%)=\frac{\mathrm{A}_{0}-\mathrm{A}_{s}}{\mathrm{~A}_{0}} \times 100
$$

where $A_{0}$ is absorbance without sample and $A_{s}$ is absorbance with sample.

\section{Statistical analysis}

Experimental data was analyzed by paired sample $t$-tests, to determine significance differences between data points $(P<0.05)$.

\section{RESULTS}

\section{Cyanide content of bamboo shoots}

The cyanide (HCN) contents of fresh and boiled sliced bamboo shoots are shown in Table 1. The cyanide content of fresh sliced bamboo shoots $(140.40 \pm 5.34 \mathrm{mg} / \mathrm{kg})$.

\section{Phytochemical composition of bamboo shoot extracts}

The fresh and boiled sliced bamboo shoot extracts both contained flavonoids and reducing sugars. However, ter- 
Table 1. Cyanide content of fresh and boiled sliced bamboo shoots

(unit: $\mathrm{mg} / \mathrm{kg}$ )

\begin{tabular}{cc}
\hline Samples & Cyanine content \\
\hline Fresh sliced bamboo shoots & $140.40 \pm 5.34$ \\
Boiled sliced bamboo shoots & ND \\
\hline
\end{tabular}

ND, not detected.

Table 2. Phytochemical components in methanol extracts of fresh and boiled sliced bamboo shoots

\begin{tabular}{cccc}
\hline Samples & $\begin{array}{c}\text { Flavo- } \\
\text { noids }\end{array}$ & $\begin{array}{c}\text { Terpe- } \\
\text { noid }\end{array}$ & $\begin{array}{c}\text { Reducing } \\
\text { sugar }\end{array}$ \\
\hline $\begin{array}{c}\text { Fresh sliced bamboo } \\
\text { shoot extracts }\end{array}$ & + & + & + \\
$\begin{array}{c}\text { Boiled sliced bamboo } \\
\text { shoot extracts }\end{array}$ & + & $\mathrm{ND}$ & + \\
\hline
\end{tabular}

+ , present of compounds; ND, not detected.

penoid was only present in fresh sliced bamboo shoot extracts (Table 2).

\section{Volatile compound profile of bamboo shoot extracts}

The volatile compound profiles of fresh and boiled sliced bamboo shoots contained 26 and 28 compounds, respectively (Table 3 ). The volatile compounds contained in the fresh sliced bamboo shoots were ethyl acetate, ethanol, ethyl butyrate, 1-pentanol, 2-pentylfuran, methoxybenzene, 1-hexanol, 2-ethylhexyl acetate, 3-ethyl-2-methyl-1, 3-hexadiene, ethyl octanoate, ecetic acid, 1-octen-3ol, 1-heptanol, 2-ethyl-1-hexanol, (E)-2-hepten-1-ol, [R$\left.\left(\mathrm{R}^{*}, \mathrm{R}^{*}\right)\right]$-2,3-butanediol, [S- $\left(\mathrm{R}^{*}, \mathrm{R}^{*}\right)$ ]-2,3-butanediol, (E)2-octen-1-ol, 1,2-dimethoxybenzene, methoxy-phenyloxime, 2-methoxyphenol, benzyl alcohol, phenol, 4methylphenol, ethyl palmitate, and 4-(1,1-dimethylpropyl)phenol. The volatile compounds contained in the boiled sliced bamboo shoots were ethyl acetate, ethanol, 2-pentanone, ethyl butyrate, ethyl benzene, 2-heptanone, 3-methyl-1-butanol, styrene, acetoin, 2-heptanol, methoxybenzene, 1-hexanol, 2-nonanone, 1-methoxy-4-methylbenzene, acetic acid, 1-octen-3-ol, 2-ethyl-1-hexanol, 2-nonanol, 2,3-butanediol, 2-undecanone, methoxy-phenyl-oxime, 2-tridecanone, (Z)-dec-4-en-1-yl propyl carbonate, benzyl alcohol, 2-methoxy-4-methylphenol, phenol, 4-methylphenol, and 4-(1,1-dimethylpropyl)phenol. All the volatile compounds identified in both the fresh and boiled sliced bamboo shoots were alcohols ( 20 compounds); furthermore, 6 were ketones; 6 were esters; 5 were aromatics; 2 were alkanes; 1 was carboxylic acids; and 1 was an amine.

\section{Total phenolic and flavonoid contents of bamboo shoots extracts}

The total phenolic and flavonoid contents of fresh and boiled sliced bamboo shoot extracts are shown in Table 4.
Table 3. Volatile compound profiles of fresh and boiled sliced bamboo shoots

\begin{tabular}{|c|c|c|c|c|}
\hline \multirow{2}{*}{ No. } & \multirow{2}{*}{ Compounds } & \multirow{2}{*}{$\begin{array}{l}\text { Retention } \\
\text { time } \\
\text { (min) }\end{array}$} & \multicolumn{2}{|c|}{ Samples } \\
\hline & & & I & II \\
\hline 1 & Ethyl acetate & 9.486 & + & + \\
\hline 2 & Ethanol & 12.240 & + & + \\
\hline 3 & 2-Pentanone & 14.306 & ND & + \\
\hline 4 & Ethyl butyrate & 19.654 & + & + \\
\hline 5 & Ethyl benzene & 30.717 & ND & + \\
\hline 6 & 2-Heptanone & 37.300 & ND & + \\
\hline 7 & 3-Methyl-1-butanol & 40.122 & ND & + \\
\hline 8 & 1-Pentanol & 40.167 & + & ND \\
\hline 9 & 2-Pentylfuran & 41.544 & + & ND \\
\hline 10 & Styrene & 42.808 & ND & + \\
\hline 11 & Acetoin & 44.686 & ND & + \\
\hline 12 & 2-Heptanol & 47.703 & ND & + \\
\hline 13 & Methoxybenzene & 48.250 & + & + \\
\hline 14 & 1-Hexanol & 49.449 & + & + \\
\hline 15 & 2-Ethylhexyl acetate & 51.119 & + & ND \\
\hline 16 & 2-Nonanone & 51.231 & ND & + \\
\hline 17 & $\begin{array}{l}\text { 3-Ethyl-2-methyl-1,3- } \\
\text { hexadiene }\end{array}$ & 52.340 & + & ND \\
\hline 18 & 1-Methoxy-4-methylbenzene & 53.413 & ND & + \\
\hline 19 & Ethyl octanoate & 53.720 & + & ND \\
\hline 20 & Acetic acid & 53.841 & + & + \\
\hline 21 & 1-Octen-3-ol & 54.331 & + & + \\
\hline 22 & 1-Heptanol & 54.604 & + & ND \\
\hline 23 & 2-Ethyl-1-hexanol & 56.208 & + & + \\
\hline 24 & (E)-2-Hepten-1-ol & 57.067 & + & ND \\
\hline 25 & 2-Nonanol & 57.593 & ND & + \\
\hline 26 & {$\left[R-\left(R^{*}, R^{*}\right)\right]-2,3-$ butanediol } & 58.230 & + & ND \\
\hline 27 & 2,3-Butanediol & 59.759 & ND & + \\
\hline 28 & {$\left[S-\left(R^{*}, R^{*}\right)\right]-2,3-$ butanediol } & 59.783 & + & ND \\
\hline 29 & 2-Undecanone & 61.006 & ND & + \\
\hline 30 & (E)-2-Octen-1-ol & 61.446 & + & ND \\
\hline 31 & 1,2-Dimethoxybenzene & 65.657 & + & ND \\
\hline 32 & Methoxy-phenyl-oxime & 66.901 & + & + \\
\hline 33 & 2-Tridecanone & 69.202 & ND & + \\
\hline 34 & $\begin{array}{l}\text { (Z)-Dec-4-en-1-yl propyl } \\
\text { carbonate }\end{array}$ & 69.756 & ND & + \\
\hline 35 & 2-Methoxyphenol & 70.534 & + & ND \\
\hline 36 & Benzyl alcohol & 71.128 & + & + \\
\hline 37 & 2-Methoxy-4-methylphenol & 73.621 & ND & + \\
\hline 38 & Phenol & 74.962 & + & + \\
\hline 39 & 4-Methylphenol & 77.121 & + & + \\
\hline 40 & Ethyl palmitate & 81.945 & + & ND \\
\hline 41 & 4-(1,1-Dimethylpropyl)phenol & 85.133 & + & + \\
\hline
\end{tabular}

I, fresh sliced bamboo shoots; II, boiled sliced bamboo shoots. + , present of compounds; ND, not detected.

In fresh sliced samples, the total phenolic and flavonoid contents were $12.12 \pm 0.12 \mathrm{mg} \mathrm{GAE} / \mathrm{dw}$ and $1.60 \pm 0.11$ $\mathrm{mg} \mathrm{QE} / \mathrm{dw}$, respectively, compared with $9.27 \pm 0.27 \mathrm{mg}$ $\mathrm{GAE} / \mathrm{dw}$ and $0.89 \pm 0.01 \mathrm{mg} \mathrm{QE} / \mathrm{dw}$, respectively, in the boiled sliced samples. These results indicate that the total phenolic and flavonoid contents of the fresh extracts were significantly $(P<0.05)$ higher than those of the boiled extracts. 
Table 4. Total phenolic and flavonoid contents in the methanol extractsof fresh and boiled sliced bamboo shoots

\begin{tabular}{ccc} 
Samples & $\begin{array}{c}\text { Total phenolic content } \\
\text { (mg GAE/dw) }\end{array}$ & $\begin{array}{c}\text { Total flavonoid content } \\
\text { (mg QE/dw) }\end{array}$ \\
\hline Fresh sliced bamboo shoot extracts & $12.12 \pm 0.12^{\mathrm{a}}$ & $1.60 \pm 0.11^{\mathrm{a}}$ \\
Boiled sliced bamboo shoot extracts & $9.27 \pm 0.27^{\mathrm{b}}$ & $0.89 \pm 0.01^{\mathrm{b}}$ \\
\hline
\end{tabular}

Different letters $(a, b)$ indicate significant differences within the same column $(P<0.05)$.

$\mathrm{GAE}$, gallic acid equivalent; $\mathrm{QE}$, quercetin equivalent.

Table 5. The radical scavenging potential of the methanol extracts of fresh and boiled sliced bamboo shoots

\begin{tabular}{ccc}
\hline & \multicolumn{1}{c}{ Samples } & $\begin{array}{c}\text { Radical scavenging potential } \\
(\% \text { inhibition at } 0.1 \mathrm{mg} / \mathrm{mL})\end{array}$ \\
\cline { 2 - 3 } & $\mathrm{ABTS}^{+{ }^{+}}$ & $\mathrm{DPPH}^{\cdot}$ \\
\hline Fresh sliced bamboo shoot extracts & $29.78 \pm 0.65^{\mathrm{a}}$ & $19.43 \pm 1.20^{\mathrm{a}}$ \\
Boiled sliced bamboo shoot extracts & $12.43 \pm 0.40^{\mathrm{b}}$ & $16.00 \pm 0.37^{\mathrm{b}}$ \\
\hline
\end{tabular}

Different letters $(a, b)$ indicate significant differences within the same column $(P<0.05)$.

Table 6. Enzyme inhibitory potential of the methanol extracts of fresh and boiled sliced bamboo shoots

\begin{tabular}{cccc}
\hline \multirow{2}{*}{ Samples } & \multicolumn{3}{c}{$\begin{array}{c}\text { Enzyme inhibition } \\
\text { (\% inhibition at 0.1 mg/mL) }\end{array}$} \\
\cline { 2 - 4 } & $\alpha$-Glucosidase & $\alpha$-Amylase & Tyrosinase \\
\hline Fresh sliced bamboo shoot extracts & $61.30 \pm 0.45^{\mathrm{a}}$ & $37.00 \pm 1.82^{\mathrm{a}}$ & $26.57 \pm 0.57^{\mathrm{a}}$ \\
Boiled sliced bamboo shoot extracts & $21.40 \pm 0.31^{\mathrm{b}}$ & $20.01 \pm 0.80^{\mathrm{b}}$ & $19.11 \pm 0.60^{\mathrm{b}}$ \\
\hline
\end{tabular}

Different letters $(a, b)$ indicate significant differences within the same column $(P<0.05)$.

\section{Radical scavenging potential of bamboo shoot extracts}

The radical scavenging potential of fresh and boiled sliced bamboo shoots extracts were determined by $\mathrm{ABTS}^{\cdot+}$ and $\mathrm{DPPH}^{*}$ assay (Table 5). The radical scavenging activity of fresh sliced bamboo shoot extracts was significantly $(P<$ 0.05 ) higher than that of the boiled extracts. ABTS ${ }^{*}$ radical monocation and $\mathrm{DPPH}^{*}$ radical scavenging activities of the fresh extracts were approximately 2.40- and 1.21fold higher, respectively, than those of the boiled extracts.

\section{Enzyme inhibition potential of bamboo shoot extracts}

The inhibitory activities of fresh and boiled sliced extracts against $\alpha$-glucosidase, $\alpha$-amylase and tyrosinase are showed in Table 6 . The inhibitory activity against all three enzymes was significantly higher $(P<0.05)$ for the fresh extracts than the boiled extracts. The highest inhibitory activity of the fresh extracts was obtained for $\alpha$-glucosidase (61.30 $\pm 0.45 \%$ inhibition), approximately 2.90-fold higher than for the boiled extracts. The percent inhibitory activity against $\alpha$-amylase and tyrosinase was approximately 1.85 - and 1.40 -fold higher, respectively, for the fresh extract than the boiled extract.

\section{DISCUSSION}

Cyanide (cyanogenic glycoside) is found in bamboo shoots. The cyanide content varies between different bamboo species and between different portions within the shoots (Satya et al., 2012). The cyanide content in sliced bamboo shoots of Dendrocalamus asper Back. was $140.40 \pm 5.34 \mathrm{mg} / \mathrm{kg}$. However, the cyanide content is higher in other Dendrocalamus species; for example, it has been shown reported at $900 \sim 1,000 \mathrm{mg} / \mathrm{kg}$ and $894 \mathrm{mg} /$ $\mathrm{kg}$ in Dendrocalamus giganteus (Ferreira et al., 1995). Furthermore, Bambusa pallida, Bambusa tulda, and Bambusa balcooa have cyanide contents of $130 \sim 270 \mathrm{mg} / \mathrm{kg}, 170 \sim$ $830 \mathrm{mg} / \mathrm{kg}$, and $620 \sim 2,150 \mathrm{mg} / \mathrm{kg}$, respectively (Satya et al., 2012). Our results and those previously reported support that the cyanide content of bamboo shoots varies between different species of bamboo, and in different portions of the shoots. The concentration of cyanide that has acute effects on human health is $0.5 \sim 3.5 \mathrm{mg} / \mathrm{kg}$ body weight (Pandey and Ojha, 2014). Thus, consumption of fresh bamboo shoot may be not beneficial for human health due to its high cyanide content.

Removing cyanide (such as through boiling, steaming, and fermentation) may be important to allow for bamboo shoot consumption. However, these cooking process may impact the nutritional content of bamboo shoots (Wang et al., 2020). We did not detect cyanide in the bamboo shoots of Dendrocalamus asper Back. after boiling for 30 min. A previous study by Rawat et al. (2015) showed that boiling for 20 min reduces the cyanide con- 
tent of whole bamboo shoots of Dendrocalamus hamiltonii and Dendrocalamus giganteus by over $87 \%$. Moreover, boiling sliced bamboo shoots for over 15 min reduces the cyanide content by over $90 \%$. These data combined with the results of the current study indicate boiling can reduce the cyanide content to an amount that does not adversely affect human health. However, the boiling process and the slicing techniques may also impact the nutritional content of bamboo shoots.

Boiling for 30 min decreased the total phenolic and flavonoid contents, and radical scavenging potential of bamboo shoots extract (Dendrocalamus asper Back.). In general, the radical scavenging potential of plant extracts is closely related to the total phenolic and flavonoid contents of plant extracts (Al Amri and Hossain, 2018). A previous study reported that heating at $100^{\circ} \mathrm{C}$ for $30 \mathrm{~min}$ decreased the amounts of major flavonoid and phenolic compounds in plant extracts (Sharma et al., 2015). Furthermore, Gunathilake et al. (2018) showed that boiling both decreased and increased the flavonoid content of edible leaves of different species. However, boiling decreased the antioxidant potential in all the different edible leaves compared with fresh leaves. In addition, the flavonoid content and antioxidant potential of the edible bamboo shoots Phyllostachys praecox C.D. and Dendrocalamus hamiltonii decreased after boiling compared to fresh samples (Zhang et al., 2011; Bajwa et al., 2018).

Our results showed that boiled sliced bamboo shoot extract had a 3.0-fold lower phenol content than fresh sliced bamboo shoots extract (Table 3 and 7). The phenol is related to antioxidant activity and is rich in bamboo shoots (Wang et al., 2020). Certain other compounds with antioxidant properties (e.g., 4-methylphenol) were also reduced in bamboo shoot extracts by boiling (Kammeyer et al., 2019). 4-Methylphenol is the major component in both fresh and boiled sliced bamboo shoot extracts (Table 7). Our results combined with those from previous studies suggest that boiling might be an effective method to decrease the flavonoid content, phenolic content, and antioxidant potential of bamboo shoots due to its ability to eliminate bio-active compounds related to antioxidant properties.

$\alpha$-Glucosidase and $\alpha$-amylase inhibitory potential of

Table 7. Major volatile compounds in bamboo shoots

\begin{tabular}{cccccc}
\hline & \multicolumn{2}{c}{$\begin{array}{c}\text { Fresh sliced } \\
\text { bamboo shoots }\end{array}$} & & \multicolumn{2}{c}{$\begin{array}{c}\text { Boiled sliced } \\
\text { bamboo shoots }\end{array}$} \\
\cline { 3 - 3 } \cline { 5 - 6 } Nompounds & $\begin{array}{c}\text { Peak } \\
\text { area (\%) }\end{array}$ & & Compounds & $\begin{array}{c}\text { Peak } \\
\text { area (\%) }\end{array}$ \\
\cline { 5 - 6 } & 4-Methylphenol & 68.15 & & 4-Methylphenol & 34.16 \\
2 & Phenol & 19.95 & & Acetic acid & 22.41 \\
3 & Acetic acid & 3.87 & & 2-Nonanone & 6.80 \\
4 & Ethyl acetate & 3.45 & & Phenol & 6.12 \\
5 & Ethanol & 0.54 & & 2-Heptanone & 5.77 \\
\hline
\end{tabular}

fresh sliced bamboo shoots extracts were significantly higher than those for boiled sliced bamboo shoots extracts (Table 6). Many natural $\alpha$-glucosidase and $\alpha$-amylase inhibitors have been identified in the groups of plant flavonoids and phenolic compounds (Ali Asgar, 2013; Sarian et al., 2017). Boiled sliced bamboo shoot extracts exhibit lower $\alpha$-glucosidase and $\alpha$-amylase inhibitory activity than fresh extracts, which may be due to the lower flavonoid and phenolic contents. Other natural products of bamboo shoots (e.g., terpenoid) have also been reported to have a role in diabetes treatment (Putta et al., 2016). We only detected terpenoid in fresh sliced bamboo shoots extract. The volatile compounds profile of bamboo shoots (Table 3) contains several compounds that inhibit $\alpha$-glucosidase and $\alpha$-amylase activity, including 2-pentyl furan and 2-methoxyphenol (guaiacol) (Fig. 1 ). These compounds were only identified in fresh extracts, with peak areas of $0.43 \%$ for 2-methoxy-phenol and $0.08 \%$ for 2-pentylfuran. Absence of compounds relating to $\alpha$-glucosidase and $\alpha$-amylase inhibition in boiled extracts may explain why the boiled extracts have lower inhibitory activity against these enzymes than fresh extracts. Therefore, boiling can eliminate compounds with $\alpha$-glucosidase and $\alpha$-amylase inhibitory activity.

4-Methylphenol is the major component of both fresh and boiled sliced bamboo shoots (Fig. 1), with peak areas of $68.15 \%$ and $34.16 \%$ for fresh and boiled sliced bamboo shoots, respectively (Table 7). 4-Methylphenol and some its derivatives exhibit anti-melanin synthesis properties, and have shown to inhibit tyrosinase higher to a greater extent than Kojic acid (Kammeyer et al., 2019). The tyrosinase inhibitory activity of fresh sliced bamboo shoots extracts had significantly higher potential than its boiled extracts. The results suggests that the decrease in 4-methylphenol by the boiling step might alter tyrosinase
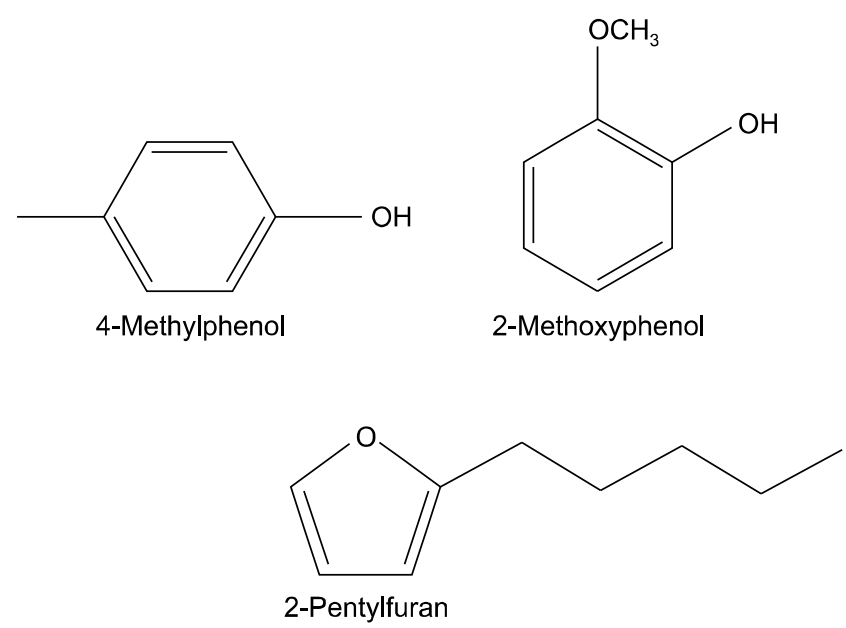

Fig. 1. The chemical structure of 4-methyphenol, 2-methoxyphenol, and 2-pentylfuran which these chemical compounds had related to biological activity such as $\alpha$-glucosidase, $\alpha$-amylase, and tyrosinase inhibitory activity. 
inhibition potential of bamboo shoots extract.

In summary, this study evaluated the cyanide content, bio-active compounds, biological properties and volatile compounds profiles of fresh and boiled sliced bamboo shoots. The cyanide content of fresh sliced bamboo shoots is $140.40 \pm 5.34 \mathrm{mg} / \mathrm{kg}$, but cyanide is undetectable in boiled sliced bamboo shoots. Furthermore, fresh sliced bamboo shoots contain flavonoids, terpenoid, and reducing sugar. However, boiling impacted the volatile compound profile of bamboo shoots and decreasing the content of several bio-active compounds, including phenolics and flavonoids. The free radical scavenging potential was similar between fresh and boiled extracts, however, higher free radical scavenging activity was observed for the former. Moreover, $\alpha$-glucosidase, $\alpha$-amylase, and tyrosinase inhibitory activities of fresh sliced bamboo shoots were higher than those of the boiled sliced bamboo shoots extracts.

These results indicate that boiled bamboo shoots are more suitable for consumption than fresh bamboo shoots, since fresh bamboo shoots have a high cyanide content. However, fresh bamboo shoots were more suitable than boiled bamboo shoots for the application in medicinal products and cosmetic products based on its biological compounds content and biological properties.

\section{ACKNOWLEDGEMENTS}

This work was supported by Program Management Unit A (Area-based), Office of Higher Education, Science, Research and Innovation Policy Council (Grant number; A13F630066) and Rajamangala University of Technology Thanyaburi.

\section{AUTHOR DISCLOSURE STATEMENT}

The authors declare no conflict of interest.

\section{REFERENCES}

Al Amri FS, Hossain MA. Comparison of total phenols, flavonoids and antioxidant potential of local and imported ripe bananas. Egypt J Basic Appl Sci. 2018. 5:245-251.

Ali Asgar M. Anti-diabetic potential of phenolic compounds: a review. Int J Food Prop. 2013. 16:91-103.

Bajwa HK, Santosh O, Koul A, Bisht MS, Nirmala C. Antioxidant content and antioxidant activity of aqueous extract from processed shoots of an edible bamboo Dendrocalamus hamiltonii Nees \& Arn. Ex Munro and their effect on hepatic lipid peroxidation levels in Balb/c mice. J Pharmacog Phytochem. 2018. 7:32483255.

Chongtham N, Bisht MS, Haorongbam S. Nutritional properties of bamboo shoots: potential and prospects for utilization as a health food. Compr Rev Food Sci Food Saf. 2011. 10:153-168.
Ferreira VLP, Yotsuyanagi K, Carvalho CRL. Elimination of cyanogenic compounds from bamboo shoots Dendrocalamus giganteus Munro. Trop Sci. 1995. 35:342-346.

Gunathilake KDPP, Ranaweera KKDS, Rupasinghe HPV. Effect of different cooking methods on polyphenols, carotenoids and antioxidant activities of selected edible leaves. Antioxidants. 2018. 7:117. https://doi.org/10.3390/antiox7090117

Kammeyer A, Willemsen KJ, Ouwerkerk W, Bakker WJ, Ratsma D, Pronk SD, et al. Mechanism of action of 4-substituted phenols to induce vitiligo and antimelanoma immunity. Pigm Cell Melanoma Res. 2019. 32:540-552.

Maoyi F, Naixun M, Fugeng Q. The bamboo production and scientific research in Thailand. J Bamboo Res. 1987. 6:54-61.

Nirmala C, Bisht MS. Bamboo: a prospective ingredient for functional food and nutraceuticals. Proceedings of the 10th World Bamboo Congress. 2015 Sep 17-22. Damyang, Korea. p 17-22.

Nongdam P, Tikendra L. The nutritional facts of bamboo shoots and their usage as important traditional foods of northeast India. Int Sch Res Notices. 2014. 2014:679073. https://doi.org/ 10.1155/2014/679073

Pandey AK, Ojha V. Precooking processing of bamboo shoots for removal of anti-nutrients. J Food Sci Technol. 2014. 51:43-50.

Panee J. Bamboo extract in the prevention of diabetes and breast cancer. In: Watson RR, editor. Complementary and Alternative Therapies and the Aging Population: An Evidence-Based Approach. Academic Press, San Diego, CA, USA. 2009. p 159177.

Pourmorad F, Hosseinimehr SJ, Shahabimajd N. Antioxidant activity, phenol and flavonoid contents of some selected Iranian medicinal plants. Afr J Biotechnol. 2006. 5:1142-1145.

Putta S, Yarla NS, Kilari EK, Surekha C, Aliev G, Divakara MB, et al. Therapeutic potentials of triterpenes in diabetes and its associated complications. Curr Top Med Chem. 2016. 16:25322542.

Rawat K, Nirmala C, Bisht MS. Processing techniques for reduction of cyanogenic glycosides from bamboo shoots. Proceedings of the 10th World Bamboo Congress. 2015 Sep 17-22. Damyang, Korea. p 1-13.

Sansenya S, Nanok K. $\alpha$-Glucosidase, $\alpha$-amylase inhibitory potential and antioxidant activity of fragrant black rice (Thai coloured rice). Flavour Fragrance J. 2020. 35:376-386.

Sansenya S, Payaka A, Wannasut W, Hua Y, Chumanee S. Biological activity of rice extract and the inhibition potential of rice extract, rice volatile compounds and their combination against $\alpha$-glucosidase, $\alpha$-amylase and tyrosinase. Int J Food Sci Technol. 2021. In press.

Sarian MN, Ahmed QU, Mat So'ad SZ, Alhassan AM, Murugesu $S$, Perumal V, et al. Antioxidant and antidiabetic effects of flavonoids: a structure-activity relationship based study. Biomed Res Int. 2017. 2017:8386065. https://doi.org/10.1155/2017/ 8386065

Satya S, Singhal P, Bal LM, Sudhakar P. Bamboo shoot: a potential source of food security. Mediterr J Nutr Metab. 2012. 5:1-10.

Sharma K, Ko EY, Assefa AD, Ha S, Nile SH, Lee ET, et al. Temperature-dependent studies on the total phenolics, flavonoids, antioxidant activities, and sugar content in six onion varieties. J Food Drug Anal. 2015. 23:243-252.

Tanaka A, Kim HJ, Oda S, Shimizu K, Kondo R. Antibacterial activity of moso bamboo shoot skin (Phyllostachys pubescens) against Staphylococcus aureus. J Wood Sci. 2011. 57:542-544.

Tanaka A, Zhu Q, Tan H, Horiba H, Ohnuki K, Mori Y, et al. Biological activities and phytochemical profiles of extracts from different parts of bamboo (Phyllostachys pubescens). Molecules. 2014. 19:8238-8260.

Wang Y, Chen J, Wang D, Ye F, He Y, Hu Z, et al. A systematic review on the composition, storage, processing of bamboo shoots: focusing the nutritional and functional benefits. J Funct 
Foods. 2020. 71:104015. https://doi.org/10.1016/j.jff.2020. 104015

Zhang JJ, Ji R, Hu YQ, Chen JC, Ye XQ. Effect of three cooking methods on nutrient components and antioxidant capacities of bamboo shoot (Phyllostachys praecox C.D. Chu et C.S. Chao). J Zhejiang Univ Sci B. 2011. 12:752-759. 